\title{
Approach to lymphoma diagnosis and management in South Africa
}

\author{
E Verburgh, MD, PhD (KUL); K Antel, MB ChB, MMed (Int Med), FCP (SA), Cert Clin Haematology (SA) \\ Division of Haematology, Department of Medicine, Faculty of Health Sciences, University of Cape Town, South Africa
}

Corresponding author: E Verburgh (estelle.verburgh@uct.ac.za)

\begin{abstract}
Lymphoma is a cancer of the lymphoid cells, with a hugely variable mode of clinical presentation, which includes constitutional symptoms, lymphadenopathy, superficial or deep-seated masses, effusions, and full blood count abnormalities such as anaemia and lymphocytosis. Lymphoma can infiltrate any organ of the body, although it typically involves lymphoid tissue or bone marrow, or both. In this article an overview is given of the diagnostic pathway and clinical diagnostic subsets that determine treatment. The treatment approach according to these subsets is best understood as: indolent lymphoma, where treatment is not urgent and the disease is not curable; aggressive lymphoma, where rapid diagnosis and treatment are of the utmost importance, with the majority of cases curable; and very aggressive lymphoma, where patients are at high risk of death at presentation, but with rapid diagnosis and treatment there is an excellent chance of long-term cure. The past decade has seen an explosion of targeted (as opposed to classic chemotherapeutic) treatments for lymphoma. These drugs target certain molecules or receptors in the tumour pathway, often with spectacularly beneficial effects that open up new horizons for cure.
\end{abstract}

S Afr Med J 2019;109(10):715-718. https://doi.org/10.7196/SAMJ.2019.v109i10.14360

\section{What is lymphoma and how prevalent is it? \\ What is lymphoma?}

Lymphoma is a cancer of the lymphoid cells and the 'cell of origin' is typically a more mature $\mathrm{B}$ cell and $\mathrm{T}$ cell. This neoplastic entity comprises $\sim 100$ different tumours of the blood-forming system. In Table 1, common lymphoma subtypes are mentioned, and Tables 1 and 2 give a practical overview of the approach to and treatment of the three major clinical groupings - the two aggressive subsets v. the indolent subsets of lymphoma.

\section{Why does lymphoma matter?}

Lymphoma has a widespread disease prevalence and is consistently among the top 10 most common malignancies worldwide. Lymphoma is also among the top 10 malignancies that are cured in the long term. ${ }^{[1]}$ Diagnostic or therapeutic nihilism inherent to certain cancer diagnoses is therefore completely inappropriate for lymphoma. It is chameleon like in its varied presentations, and also mimics and is overshadowed by common diseases such as tuberculosis (TB). Therefore, despite its lower prevalence compared with TB or HIV in South Africa (SA), lymphoma should be on the list of differential diagnoses of many commonly occurring disease presentations.

\section{What is the incidence of lymphoma and its impact on society? Lymphoma incidence in the international v. African context}

A recent age-standardised incidence rate of all subtypes of lymphoma in Europe was 24.5 per $100000 .^{[2]}$ Lymphoma has a 10 - 100-fold increased incidence in HIV-infected persons - in an academic complex in Johannesburg, SA, an almost $20 \%$ increase was seen in the proportion of HIV-positive lymphoma patients in the previous decade. ${ }^{[3,4]}$ However, as SA is the epicentre of the HIV pandemic, this increase is modest, and certainly not reflected in the national cancer registry incidence data that are inappropriately low at $\sim 5$ per 100000 . With the more pressing concerns of HIV and TB, as well as poor access to healthcare, we are failing to diagnose and report large numbers of patients with lymphoma. ${ }^{[5]}$

Lymphoma prognosis in the international v. African context Because of exponentially increasing gains in treatment advances in developed countries, lymphoma has shown significantly improved outcomes in the past decade compared with earlier data, a trend that is expected to continue. ${ }^{[6]}$ The subtype incidence and outcome of lymphoma vary throughout different regions of the world, but in sub-Saharan Africa, especially, the outcome of lymphoma is highly affected by local factors, such as lack of diagnostic pathways, concomitant HIV, presumption of TB and poor access to treatment at expert referral centres. Haematological malignancies are a significant cause of death and disability in this region; nevertheless, data on the presentation and outcome of lymphoma remain scarce. ${ }^{[7,8]}$ In cases associated with HIV, outcome after lymphoma treatment is poor compared with that in resource-rich regions, where HIV status does not necessarily influence the outcome. ${ }^{[9]}$

\section{Pathophysiology}

The best way of explaining cancer development is to start with the cell-of-origin pathogenesis. Blood-forming stem cells differentiate into a myriad of cell types, and lymphoma occurs when a specific cell type at various stages along lymphocyte development undergoes malignant dysregulation, resulting in tumour growth. The lymphoid malignancies are unique by the sheer magnitude of developmental stages and cell types that can give rise to different subtypes of lymphoma, as reflected in the current World Health Organization (WHO) classification of lymphomas. ${ }^{[10]}$

\section{Diagnostic pathway}

Five typical clinical 'presentation syndromes' of lymphoma and typical clinical confounders

- B symptoms (consisting of a triad of unexplained temperature of $>38^{\circ} \mathrm{C}$, drenching night sweats and $>10 \%$ weight loss in previous 6 months) 
- The obvious clinical confounder is the constitutional symptoms of solid-organ cancers, connective tissue diseases, endocrine syndromes, and especially of infectious diseases such as HIV and TB.

- Significant lymphadenopathy that is non-painful, often symmetric, with rubber-hard consistency. Although lymphoma can be present in smaller nodes, the 'index diagnostic' lymph node in lymphoma is $>1.5 \mathrm{~cm}$ and present for $>3$ weeks

- In the previous article, ${ }^{[11]}$ we suggest a diagnostic algorithm to ensure that lymphadenopathy related to $\mathrm{TB}$ is successfully differentiated from lymphoma.

- Cytopenias, especially anaemia, resulting from bone marrow invasion with suppression of normal blood cell production

- The differential diagnosis can be another haematological myeloid malignancy such as acute myeloid leukaemia (AML) or myelodysplastic syndrome (MDS).

- However, the differential diagnoses of cytopenias are vast and span across immunological and systemic diseases.

- Lymphocytosis due to lymphoma invading the bone marrow, with subsequent spill of tumour cells in the blood stream

- These blood-borne or 'leukaemic' lymphoma cells can be easily typified and diagnosed as malignant. The pitfall for a missed diagnosis is when the differential count is not requested. Determination of white cell count should always include a differential count. By the same logic, an abnormal 'ward $\mathrm{Hb}$ ' should always be followed by the full blood count (FBC), differential count and blood film.

- Tumour masses that can quietly grow in body cavities, eventually causing symptoms by disturbance of function. These can grow contiguous to lymph node sites, such as lymphoblastic lymphoma causing a mediastinal mass and pleural effusions, or a B-cell lymphoma causing obstruction along the gastrointestinal tract; or they can be remote to lymph node sites, such as follicular lymphoma presenting in the humerus or skin, or primary central nervous system lymphoma presenting as a brain tumour

- The only way to establish the cause of a growth or mass is to carefully seek a histological diagnosis. Often this is enabled by imaging.

- Lymphoma is the primary cause of a mediastinal mass in the young and remains an important differential diagnosis of lung cancer, even in older patients.

- In patients with pleural effusion a diagnosis may remain elusive, and empirical TB treatment may be started. Although perfectly legitimate in a TB-endemic area, patients receiving empiric TB treatment should be followed up after 2 weeks, and one should keep in mind an alternative diagnosis, such as lymphoma. ${ }^{[12]}$

\section{Approach to diagnosis based on clinical presentation}

- Lymphadenopathy and tumour masses suspicious of lymphoma. Increasingly, core biopsy with a wide needle $(14 \mathrm{G})$ is used for diagnosis of tumour masses, and excision biopsy is used according to surgical indication. Fine-needle aspiration (FNA) cytology is never sufficient for lymphoma diagnosis (see previous article). ${ }^{[11]}$ 'The issue is to get the tissue.' Gaining timely advice from an expert in lymphoma diagnosis can avoid time and life lost due to fruitless FNA and aimless biopsies. In patients with same-size moderately enlarged lymphadenopathy, the cervical area is always preferred rather than the axillary area and the inguinal area for diagnostic biopsies. This increases diagnostic yield and avoids false-negative results.

- Substantial lymphocytosis. In these cases, the diagnosis of a lymphoma can easily be made on flow cytometry of blood. Acute lymphoblastic leukaemia (ALL) can be diagnosed in blood and is the leukaemic counterpart of acute lymphoblastic lymphoma. However, in clinical practice a sustained lymphocytosis is most often seen with the indolent lymphomas, such as chronic lymphocytic leukaemia (CLL). The diagnosis becomes more urgent if the lymphocytosis is accompanied by signs of bone marrow failure, such as anaemia and thrombocytopenia. Bone marrow examination is carried out at the discretion of the haematologist.

\section{Helpful non-full blood count tests when considering the} diagnosis of lymphoma

- Elevated lactate dehydrogenase (LDH). The more advanced the stage and the more aggressive the lymphoma, the higher the LDH. LDH is not solely related to red cell destruction syndromes or acute liver and cardiac states and is a mandatory and useful test when searching for malignancy. Note that a normal LDH does not exclude lymphoma.

- Elevated creatinine and uric acid. A sudden increase in creatinine in the absence of pre-existing renal insult, and accompanied by a high uric acid and LDH, is suggestive of an aggressive lymphoma

- Raised erythrocyte sedimentation rate (ESR). Not specific enough to use as a screening test.

- Elevated canalicular liver enzymes (alkaline phosphatase and gamma-glutamyl transferase). These are likewise nonspecific to lymphoma, but in this setting must prompt consideration of the liver as a site of lymphomatous infiltration.

- Coombs positivity. Accompanied by low haptoglobin and increased reticulocyte count points to an associated haemolytic anaemia.

\section{Approach to the diagnostic and staging procedures of lymphoma}

In some lymphoma cases, the diagnosis is straightforward and the patient can be referred for staging and treatment. However, many patients are under observation, with a possible differential diagnosis of lymphoma. In these cases, it is advised to consult a clinical haematologist or an oncologist early to guide the diagnostic biopsy of suspicious tissue.

Typically, diagnostic and staging procedures include the triad of:

- Imaging, usually a computed tomography (CT) scan of the neckthorax-abdomen-pelvis or other affected area, but increasingly a nuclear study with fluorodeoxyglucose (FDG)-positron emission tomography (PET)/CT is employed for enhanced metabolic screening of a neoplasm. ${ }^{[13]}$

- Histology of a tumour mass or lymph node excision biopsy, including genetic and molecular techniques to enhance diagnostic differentiation.

- Bone marrow examination, including cytogenetic and molecular tests.

These procedures are adapted to the subtype of lymphoma, e.g. in certain low-grade lymphomas with circulating tumour cells (leukaemic phase of lymphoma), flow cytometry on blood and a clinical evaluation may be cost-effective and sufficient for diagnosis, whereas an FDG-PET/CT has become preferable as baseline investigation for Hodgkin lymphoma and may obviate the need for a bone marrow examination.

\section{Restaging investigations after chemotherapy}

Restaging investigations after chemotherapy are based on the following considerations:

- Is the treatment non-curative? Then a clinical evaluation may trump invasive tests or even imaging.

- Is the treatment curative? Evaluation of the areas of initial disease is mandatory to restage and confirm remission. 


\section{Treatment and prognostic approach}

Based on cell-of-origin tumour histology, lymphoma is divided into Hodgkin lymphoma and non-Hodgkin lymphoma:

- Hodgkin lymphoma (HL). There is a simple disease classification and a straightforward excellent prognosis. Classic HL has a $>80 \%$ cure rate. ${ }^{[14]}$ - Non-Hodgkin lymphoma (NHL). There are 100 NHL subtypes based on cell of origin, exhibiting extremely diverse predilection for site and degree of disease expression. Moreover, they display

Table 1. Three clinical lymphoma groups and approach to diagnosis

\begin{tabular}{|c|c|c|c|c|c|}
\hline $\begin{array}{l}\text { Clinical } \\
\text { lymphoma } \\
\text { disease } \\
\text { expression }\end{array}$ & $\begin{array}{l}\text { Cell-of-origin } \\
\text { causing } \\
\text { lymphoma }\end{array}$ & $\begin{array}{l}\text { Typical } \\
\text { demographics }\end{array}$ & $\begin{array}{l}\text { Typical lymphoma } \\
\text { subtypes } \\
\text { encountered in } \\
\text { clinical practice }\end{array}$ & $\begin{array}{l}\text { Risk to patient if } \\
\text { undiagnosed and } \\
\text { untreated }\end{array}$ & Diagnostic urgency \\
\hline $\begin{array}{l}\text { Low-grade or } \\
\text { indolent } \\
\text { lymphoma }\end{array}$ & $\begin{array}{l}\text { Mature B cells } \\
\text { and less often } \\
\text { mature T cells }\end{array}$ & $\begin{array}{l}\text { Usually a disease } \\
\text { of the elderly, } \\
\text { peak incidence } \\
\sim 60 \text { years }\end{array}$ & $\begin{array}{l}\text { Chronic lymphocytic } \\
\text { leukaemia } \\
\text { Follicular lymphoma } \\
\text { Splenic lymphomas }\end{array}$ & $\begin{array}{l}\text { Not all indolent } \\
\text { lymphomas need } \\
\text { treatment } \\
\text { Treatment delay } \\
\text { unlikely to affect } \\
\text { mortality }\end{array}$ & $\begin{array}{l}\text { Less urgent to diagnose and easier } \\
\text { Disease often spills into bloodstream } \\
\text { ('leukaemic'), being present in bone } \\
\text { marrow, or is diagnosed on a large } \\
\text { tumour mass, or occurs in large spleen }\end{array}$ \\
\hline $\begin{array}{l}\text { High-grade } \\
\text { or aggressive } \\
\text { lymphoma }\end{array}$ & $\begin{array}{l}\text { Mature B cells } \\
\text { and less often } \\
\text { mature T cells, } \\
\text { occurring at an } \\
\text { intermediate } \\
\text { developmental } \\
\text { stage }\end{array}$ & $\begin{array}{l}\text { Wide spectrum } \\
\text { of occurrence } \\
\text { across age groups, } \\
\text { prognosis better } \\
\text { in the young }\end{array}$ & $\begin{array}{l}\text { Diffuse large B-cell } \\
\text { lymphoma } \\
\text { Hodgkin lymphoma } \\
\text { Peripheral T-cell } \\
\text { lymphoma }\end{array}$ & $\begin{array}{l}\text { Undiagnosed and } \\
\text { untreated patients } \\
\text { have a risk of dying } \\
\text { within weeks - } \\
\text { months }\end{array}$ & $\begin{array}{l}\text { Early diagnosis is crucial: advanced } \\
\text { stage of disease diminishes cure rate and } \\
\text { increases mortality } \\
\text { Tumour lysis syndrome is possible, } \\
\text { either spontaneously or on initiation of } \\
\text { treatment }\end{array}$ \\
\hline $\begin{array}{l}\text { Very-high- } \\
\text { grade or very } \\
\text { aggressive } \\
\text { lymphoma }\end{array}$ & $\begin{array}{l}\text { Immature B } \\
\text { or T blastic } \\
\text { cells or Burkitt } \\
\text { cells with high } \\
\text { turnover rate }\end{array}$ & $\begin{array}{l}\text { Wide spectrum } \\
\text { of occurrence } \\
\text { across age groups, } \\
\text { prognosis better } \\
\text { in the young }\end{array}$ & $\begin{array}{l}\text { Acute lymphoblastic } \\
\text { lymphoma } \\
\text { Burkitt lymphoma } \\
\text { Plasmablastic } \\
\text { lymphoma }\end{array}$ & $\begin{array}{l}\text { Undiagnosed and } \\
\text { untreated patients } \\
\text { have a risk of dying } \\
\text { within days - weeks }\end{array}$ & $\begin{array}{l}\text { Refer without delay (attention to } \\
\text { hydration and renal protection) } \\
\text { High lactate dehydrogenase can point to } \\
\text { tumour lysis syndrome }\end{array}$ \\
\hline
\end{tabular}

Table 2. Three clinical lymphoma groups and approach to treatment

\begin{tabular}{|c|c|c|c|c|}
\hline $\begin{array}{l}\text { Clinical } \\
\text { lymphoma } \\
\text { disease expression }\end{array}$ & $\begin{array}{l}\text { Initial treatment } \\
\text { approach and } \\
\text { timing of therapy }\end{array}$ & $\begin{array}{l}\text { Common chemotherapy } \\
\text { treatment regimens } \\
\left(+/- \text { rituximab }^{\star}\right)\end{array}$ & $\begin{array}{l}\text { Stem cell and biological } \\
\text { treatment possibilities }\end{array}$ & Expected treatment outcome \\
\hline $\begin{array}{l}\text { Low-grade } \\
\text { or indolent } \\
\text { lymphoma }\end{array}$ & $\begin{array}{l}\text { Treat } \\
\text { symptomatically, } \\
\text { i.e. based on effects } \\
\text { of disease burden } \\
\text { If asymptomatic, } \\
\text { watch and wait }\end{array}$ & $\begin{array}{l}\text { Chlorambucil } \\
\text { Bendamustine } \\
\text { CHOP } \\
\text { CHOEP } \\
\text { CVP } \\
\text { FC }\end{array}$ & $\begin{array}{l}\text { Ibrutinib }^{\dagger} \text { - a bruton kinase } \\
\text { inhibitor } \\
\text { Curative treatment with } \\
\text { allogeneic stem cell transplant } \\
\text { is reserved for young patients } \\
\text { with a high burden of disease }\end{array}$ & $\begin{array}{l}\text { Largely non-curative treatment with aim } \\
\text { to reduce disease burden and restore to } \\
\text { asymptomatic state, unless exceptionally, } \\
\text { allogeneic stem cell transplant }\end{array}$ \\
\hline $\begin{array}{l}\text { High-grade } \\
\text { or aggressive } \\
\text { lymphoma }\end{array}$ & $\begin{array}{l}\text { Treat aggressively } \\
\text { and without delay, } \\
\text { even if only a small } \\
\text { disease burden }\end{array}$ & $\begin{array}{l}\text { First line: } \\
\text { CHOP } \\
\text { Da-EPOCH } \\
\text { ABVD +/- radiotherapy } \\
\text { BEACOPP and } \\
\text { radiotherapy } \\
\text { Second line: } \\
\text { DHAP } \\
\text { ICE } \\
\text { GDP } \\
\text { IGEV }\end{array}$ & $\begin{array}{l}\text { Nivolumab }^{\dagger} \text { and } \\
\text { pembroluzimab }^{\dagger} \text { are } \\
\text { checkpoint inhibitors } \\
\text { Lenalidomide }^{\dagger} \text { is an } \\
\text { immunomodulator } \\
\text { In patients not achieving } \\
\text { remission, or at high risk } \\
\text { of relapse, autologous stem } \\
\text { cell transplant, or less } \\
\text { often, allogeneic stem cell } \\
\text { transplant, can be curative }\end{array}$ & $\begin{array}{l}\text { Intent of treatment is curative } \\
\text { Predictors of prognosis include: } \\
\text { Age } \\
\text { Disease extent } \\
\text { Site of disease } \\
\text { Raised LDH } \\
\text { Anaemia } \\
\text { Typical population survival rates for } \\
\text { aggressive NHL patients are } ~ 50 \% \text { and } \\
>80 \% \text { for HL patients }\end{array}$ \\
\hline $\begin{array}{l}\text { Very-high-grade } \\
\text { or } \\
\text { very aggressive } \\
\text { lymphoma }\end{array}$ & $\begin{array}{l}\text { Treat aggressively } \\
\text { and without delay, } \\
\text { high likelihood } \\
\text { of tumour lysis } \\
\text { syndrome }\end{array}$ & $\begin{array}{l}\text { Intense inpatient chemo- } \\
\text { therapy regimens, e.g.: } \\
\text { Hyper-CVAD } \\
\text { CODOX-M-IVAC } \\
\text { Da-EPOCH +/- dose- } \\
\text { dense rituximab }\end{array}$ & $\begin{array}{l}\text { High-risk disease qualifies for } \\
\text { stem cell transplant } \\
\text { An exciting new therapy for } \\
\text { resistant disease is } \\
{\mathrm{CAR}-\mathrm{T}^{\dagger} \text { cells utilising }}_{\text {adoptive immunotherapy }} \\
\text { directed at tumour cells }\end{array}$ & $\begin{array}{l}\text { Intent of treatment is curative and can } \\
\text { be achieved in } 40-80 \% \text { of patients, } \\
\text { depending on age and growth and genetic } \\
\text { characteristics of the tumour }\end{array}$ \\
\hline \multicolumn{5}{|c|}{$\begin{array}{l}\text { CHOP = Cyclophosphamide, Hydroxydaunorubicin (doxorubicin), Oncovin (vincristine), Prednisone; CHOEP = CHOP with Etoposide; CVP = Cyclophosphamide, Oncovin (Vincristine), } \\
\text { Prednisone; FC = Fludarabine, Cyclophosphamide; Da-EPOCH = Dose-adjusted-Etoposide, Prednisone, Oncovin (vincristine), Cyclophosphamide, Hydroxydaunorubicin (doxorubicin); } \\
\text { ABVD = Adriamycin, Bleomycin, Vincristine, Dacarbazine; BEACOPP = Bleomycin, tetoposide, doxorubicin (Adriamycin), Cyclophosphamide, Oncovin (vincristine), Procarbazine, Prednisone; } \\
\text { DHAP = Dexamethasone, High-dose Ara C (cytarabine), Platinol (cisplatin); ICE = Ifosfamide, Cisplatin, Etoposide; GDP = Gemcitabine, Dexamethasone, Platinol (cisplatin); IGEV = Ifosfamide, } \\
\text { GEmcitabine, Vinorelbine, prednisone; Hyper-CVAD = Cyclophosphamide, Vincristine, doxorubicin (Adriamycin), Dexamethasone in course A, and Methotrexate and Cytarabine in course B; } \\
\text { CODOX-M-IVAC = Cyclophosphamide, Oncovin (vincristine), DOXorubicin-Methotrexate-Ifosfamide, VP-16 (etoposide), Ara-C (cytarabine); CAR-T = Chimeric Antigen Receptor T-cell therapy; } \\
\text { LDH = lactate dehydrogenase; NHL = non-Hodgkin lymphoma; HL = Hodgkin lymphoma. } \\
\text { "Rituximab forms an integral part of most B-cell lymphoma chemotherapy regimens. } \\
\text { 'Novel biological drugs. }\end{array}$} \\
\hline
\end{tabular}


vastly disparate behaviour clinically; therefore, clinically and with regard to treatment, it is most useful to approach lymphoma based on three clinical presentation patterns as set out in Table $1:^{[15}$

- the low-grade or indolent lymphoma group

- the high-grade or aggressive lymphoma group

- the very-high-grade or very aggressive lymphoma group.

Certain characteristics upfront predict the grade of aggressiveness of the lymphoma. Making the correct subtype diagnosis is becoming increasingly important, as treatment for lymphoma is progressively tailored to subtype. Once the diagnostic subtype is known, treatment can be approached within the framework of one of the three clinical groups.

\section{Lymphoma is treated with classic chemotherapeutic agents and new targeted biological therapies}

Chemotherapy treatment is typically delivered in cycles, scheduled to recur at 2 - 4-week intervals, sometimes augmented by radiotherapy. Common chemotherapy regimens used in commonly occurring lymphomas are listed in Table 2. Patients with high-risk or aggressive disease are initially hospitalised, but most treatment can be delivered on an outpatient basis. Chemotherapy combinations are used and, increasingly, biological therapy is added. The most well-known biological drug in lymphoma and the first drug in its class for antitumour cell antibody therapy, is rituximab, an anti-CD20 humanised monoclonal antibody therapy. Nevertheless, the backbone of most initial chemotherapy schedules for lymphoma remains corticosteroid therapy. Increasingly, the malignant activation pathways in lymphoma growth are being targeted by novel biological drugs, of which a few examples are given in Table 2. These 'targeted' drugs are novel in action and hold the promise of revolutionising lymphoma therapy. With a large number of these powerful novel agents being developed, the future of lymphoma treatment looks better than ever, but the basics of a good clinical diagnostic approach through early and efficient diagnosis, followed by correct treatment, remain foundational to the management of lymphoma to optimise outcomes.

Declaration. None.

Acknowledgements. Our colleague, Prof. Vernon Louw, for critical reading and expert advice on the manuscript, and Ms Jenna Oosthuizen for research co-ordination in our division.
Author contributions. EV wrote the manuscript. KA gave expert input and edited the manuscript.

Funding. EV received support from the National Research Foundation Thuthuka (grant number TTK14052267787). KA has been supported by the US National Institutes of Health, Fogarty International Center (grant number D43-TW010345 and grant number D43-TW010543); and the Peter Jacobs Bursary Trust.

Conflicts of interest. None.

1. Rachet B, Maringe C, Nur U, et al. Population-based cancer survival trends in England and Wales up to 2007: An assessment of the NHS cancer plan for England. Lancet Oncol 2009;10(4):351-369. https:// doi.org/10.1016/s1470-2045(09)70028-2

2. Sant M, Allemani $\mathrm{C}$, Tereanu $\mathrm{C}$, et al. Incidence of hematologic malignancies in Europe by morphologic subtype: Results of the HAEMACARE project. Blood 2010;116(19):3724-3734. https:// doi.org/10.1182/blood-2010-05-282632

3. Patel M, Philip V, Fazel F. Human immunodeficiency virus infection and Hodgkin's lymphoma in South Africa: An emerging problem. Adv Hematol 2011;2011:578163. https://doi.org/10.1155/2011/578163

4. Wiggill TM, Mantina H, Willem P, Perner Y, Stevens WS. Changing pattern of lymphoma subgroups at a tertiary academic complex in a high-prevalence HIV setting: A South African perspective. J Acquir Immune Defic Syndr 2011;56(5):460-466. https://doi.org/10.1097/QAI.0b013e31820bb06a

5. World Health Organization. WHO Report 2011: Global Tuberulosis Control. Geneva: WHO, 2011.

6. De Angelis R, Sant M, Coleman MP, et al. Cancer survival in Europe $1999-2007$ by country and age: Results of EUROCARE-5. A population-based study. Lancet Oncol 2014;15(1):23-34. https://doi. org/10.1016/S1470-2045(13)70546-1

7. Parkin DM. The evolution of the population-based cancer registry. Nat Rev Cancer 2006;6(8):603-612. Parkin DM. The evolution of the
https://doi.org/10.1038/nrc1948

8. Parkin DM, Sitas F, Chirenje M, Stein L, Abratt R, Wabinga H. Part I: Cancer in indigenous Africans - burden, distribution, and trends. Lancet Oncol 2008;9(7):683-692. https://doi.org/10.1016/s14702045(08)70175-x

9. Coutinho R, Pria AD, Gandhi S, et al. HIV status does not impair the outcome of patients diagnosed with diffuse large B-cell lymphoma treated with R-CHOP in the cART era. AIDS 2014;28(5):689-697. https://doi.org/10.1097/QAD.0000000000000133

10. Swerdlow SH, Campo E, Pileri SA, et al. The 2016 revision of the World Health Organization classification of lymphoid neoplasms. Blood 2016;127(20):2375-2390. https://doi.org/10.1182/ blood-2016-01-643569

11. Antel K, Verburgh E. Lymphadenopathy in a tuberculosis-endemic area: Diagnostic pitfalls and suggested approach. S Afr Med J 2019;109(10):712-714. https://doi.org/10.7196/SAMJ.2019. v109i10.14361

12. Wilson D, Nachega J, Morroni C, Chaisson R, Maartens G. Diagnosing smear-negative tuberculosis using case definitions and treatment response in HIV-infected adults. Int J Tuberc Lung Dis 2006;10(1):31-38.

13. Kostakoglu L, Cheson BD. Current role of FDG PET/CT in lymphoma. Eur J Nucl Med Mol Imaging 2014;41(5):1004-1027. https://doi.org/10.1007/s00259-013-2686-2

14. Borchmann P, Haverkamp H, Diehl V, et al. Eight cycles of escalated-dose BEACOPP compared with 4. Borchmann P, Haverkamp H, Diehl V, et al. Eight cycles of escalated-dose BEACOPP compared with
four cycles of escalated-dose BEACOPP followed by four cycles of baseline-dose BEACOPP with or without radiotherapy in patients with advanced-stage Hodgkin's lymphoma: Final analysis of the HD12 trial of the German Hodgkin Study Group. J Clin Oncol 2011;29(32):4234-4242. https://doi. org/10.1200/JCO.2010.33.9549

15. Connors JM. Non-Hodgkin lymphoma: The clinician's perspective - a view from the receiving end. Mod Pathol 2013;26(Suppl 1):S111-S118. https://doi.org/10.1038/modpathol.2012.184

Accepted 26 August 2019. 